\title{
Karakteristik Permen Jeli Susu Kambing yang Ditambahkan Berbagai Konsentrasi Jus Kulit Buah Naga Merah (Hylocereus polyrhizus)
}

\section{Characteristics of Goat Milk Jelly Candy Incorporated With Various Concentrations of Red Dragon Fruit (Hylocereus polyrhizus) Peel Juice}

\author{
Yannisa Pertiwi', Afriani Sandra', and Aronal Arief Putra ${ }^{1}$ \\ 'Department of Technology of Animal Products, Faculty of Animal Science, Universitas Andalas, \\ Kampus Limau Manis, 25163, West Sumatra, Indonesia \\ afrianisandra@ansci.unand.ac.id
}

\begin{abstract}
Diterima : : o1 Februari 2019
Disetujui : :17 Februari 2019

Diterbitkan : :21 Februari 2019
\end{abstract}

\begin{abstract}
Abstrak: $\quad$ Pengaruh penambahan jus kulit buah naga merah (Hylocereus polyrhizus) terhadap kualitas jeli susu kambing telah diteliti. Jus tersebut disiapkan dengan menghomogenkan kulit buah naga merah dan air pada rasio 4:1. Berbagai jenis konsentrasi jus kulit buah naga merah terhadap konsentrasi susu yaitu o, 2, 4, 6, dan $8 \%$ telah ditambahkan pada formulasi permen jeli. Setelah dimasak, kadar air, $p H$, dan warna $\left(L^{*}, a, b^{*}\right)$ sampel diuji. Hasil dari penelitian ini menunjukkan bahwa penambahan jus kulit buah naga merah meningkatkan kadar air sampel, sedangkan $p H$ sampel menurun secara signifikan. Pada saat yang sama, lightness $\left(L^{*}\right)$ dan yellowness $\left(b^{*}\right)$ sampel menurun, tetapi redness $\left(a^{*}\right)$-nya meningkat. Kesimpulannya, 8\% kulit buah naga merah berkontribusi dalam menghasilkan redness yang lebih pekat, sehingga dapat menjadi pilihan zat pewarna untuk menghasilkan warna yang menarik pada pembuatan permen jeli susu kambing.
\end{abstract}

Kata Kunci: buah naga merah, kulit, permen jeli, redness, susu kambing.

Abstract: The effect of red dragon fruit (Hylocereus polyrhizus) peel juice incorporation on quality of goat milk jelly candy was studied. The juice was prepared by homogenizing red dragon fruit peel with water in ratio 4:1. Various concentration of red dragon fruit peel juice to concentration of milk used i.e. o, 2, 4, 6, and 8\% were incorporated on jelly candy formulation. After cooked, moisture content, $p H$, and color $\left(L^{*}, a^{*}, b^{*}\right)$ of samples were determined. The result of this study showed incorporation of red dragon fruit peel juice was significantly increase moisture content of sample, while $\mathrm{pH}$ of sample was significantly decreased. At the same time, lightness $\left(L^{*}\right)$ and yellowness $\left(b^{*}\right)$ of samples were decreased, but redness $\left(a^{*}\right)$ was considerably increased. In conclusion, $8 \%$ of red dragon fruit peel juice was contributed to produce intense redness formation and thus could be an alternative colorant to provide attractive color for goat milk jelly candy production.

Keywords: goat milk, jelly candy, peel, red dragon fruit, redness.

\section{Introduction}

Dairy products play an important role as protein source for human daily consumption. Dairy cattle are dominated world milk production and thus being important dairy animal for most commercial dairy products. On the other side, dairy goat with its dairy products was found in limited quantity due to its typical aroma and taste and thus led to less goat milk preferences. In fact, consumption of goat milk probably more related to traditional medical therapy rather than consumed for sensory preference reason.
Jelly candy is commonly produced from a combination of various hydrocolloid types with sugar-rich components. Water is the main solvent on mixing such other ingredients and then determine final textural attributes of jelly candy produced. Goat milk could be an alternative to replace water addition on jelly candy manufacturing, in which, at the same time also benefit for diversification of dairy goat products.

Dragon fruit is attributed for its attractive color particularly for red dragon fruit (Hylocereus polyrhizus) species. Its edible part could be 
consumed directly in form of juices or develop into various desserts. Moreover, its peel could be useful as natural colorant applied on jelly candy instead of being unusable by-products.

Many previous researches were conducted related to the using of dragon fruit in various food products such as jam [1], jelly [2], and yogurt [3, 4, 5, 6], while limited reports of dragon fruit peel utilization found on cookies [7] and frozen yogurt [8]. Application of dragon fruit peel on jelly candy produced from goat milk is important to be studied. Moisture, $\mathrm{pH}$, and color are some important characteristics deal with jelly candy and red dragon fruit properties, and accordingly necessity to be evaluated.

\section{Material and Methods}

\subsection{Material}

Goat milk were obtained from a local dairy goat farm located in Korong Gadang, Kuranji, Padang,
West Sumatra. Red dragon fruits (Hylocereus polyrhizus) were bought from Pasar Baru, Limau Manis, Padang, West Sumatra. Other ingredients used on this study were gelatin, HFS (high fructose syrup), citric acid powder, and sugar.

\subsection{Methods}

\subsubsection{Red dragon fruit peel juice preparation}

After edible part removal, obtained red dragon fruit peel were resized into small pieces, added with water, and ground using a blender. The ratio of dragon fruit: water used on this study was 4:1 as applied by a reference [9].

\subsubsection{Red dragon fruit peel juice preparation}

After adapted the formulation [10] with the incorporating red dragon fruit peel juice, a new formulation (Table 1) was developed to ensure the quality of goat milk jelly candy meet the texture requirement.

Table 1. Formulation of goat jelly candy incorporated with various concentration of red dragon fruit peel juice.

\begin{tabular}{|c|c|c|c|c|c|}
\hline \multirow{2}{*}{ Formulation } & \multicolumn{5}{|c|}{ Treatment } \\
\hline & $\mathbf{A}$ & $\mathbf{B}$ & $\mathrm{C}$ & $\mathbf{D}$ & $\mathbf{E}$ \\
\hline Goat milk & 100 & 100 & 100 & 100 & 100 \\
\hline Red dragon fruit peel juice & 0 & 2 & 4 & 6 & 8 \\
\hline Gelatin & 15 & 15 & 15 & 15 & 15 \\
\hline Sucrose & 15 & 15 & 15 & 15 & 15 \\
\hline Water & 3 & 3 & 3 & 3 & 3 \\
\hline HFS (high fructose syrup) & 50 & 50 & 50 & 50 & 50 \\
\hline Citric acid & 0.2 & 0.2 & 0.2 & 0.2 & 0.2 \\
\hline
\end{tabular}

* formulation was provided in percent of goat milk

\subsubsection{Cooking procedure}

Cooking procedure was applied [10] with modification. Sucrose (75 g), HFS (250 g), and water $(15 \mathrm{ml})$ were mixed and heated for $10 \mathrm{~min}$ until well dissolved. After that, the mixture were combined with goat milk (50o $\mathrm{ml})$ and homogenized. Subsequently, viscous form of gelatin prepared by steaming gelatin sheet $(75 \mathrm{~g})$ were added, homogenized, heated in low heat cooking $\left(70-80^{\circ} \mathrm{C}\right)$, and stirred constantly for 1 hour. After cooled in room temperature, citric acid (1 g) were added and mixed completely. Subsequently, jelly paste was divided into 5 lots, added with red dragon fruit peel juice $(\mathrm{A}=0 \%, \mathrm{~B}=2 \%, \mathrm{C}=4 \%, \mathrm{D}=6 \%$, and $\mathrm{D}=8 \%$ ), homogenized, poured into silicone mold, stand for 1 hour in room temperature, wrapped, and stored at refrigerated temperature for 24 hours. Jelly candies were removed from the mold before taken for laboratory analyses.

\subsubsection{Laboratory analyses}

Moisture content was determined following guidelines of AOAC [11]. pH was determined using a $\mathrm{pH}$ meter (Hanna Instruments, USA). Calibration was conducted at $\mathrm{pH} 4$ and 7 before determination of diluted sample in distilled water (ratio 5:1) applied. Lightness $\left(\mathrm{L}^{*}\right)$, redness $\left(\mathrm{a}^{*}\right)$, and yellowness $\left(\mathrm{b}^{*}\right)$ determination were conducted using a hunter lab colorimeter (Color Flex EZ, USA).

\subsubsection{Statistical analysis}

Data were statistically analyze using SPSS program. Compare means was determined using ANOVA. Duncan was applied to determine significant level at $0.05 \%$.

\section{Result and Discussion}

Moisture content of goat milkjelly candy incorporated with various concentrations of red dragon fruit peel juice is presented in Figure 1. 


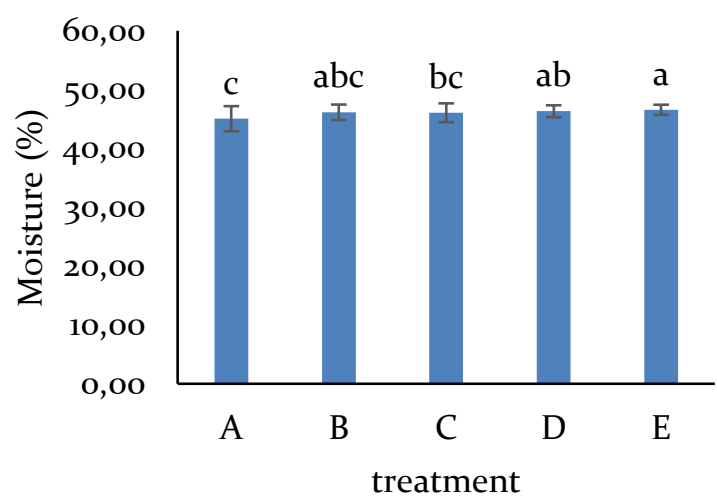

Figure 1. Moisture content of goat milk jelly candy incorporated with various concentrations of red dragon fruit peel juice

In general, increasing trend of moisture with increasing concentration of red dragon peel juice was obtained on this study $(\mathrm{P}<0.05)$. This occurrence was associated with obtained moisture content of dragon fruit peel juice $(92.50 \%)$. Besides, dragon fruit peel also known as source of pectin (10.8\%) and might play a significant role to retain water on jelly produced [12].

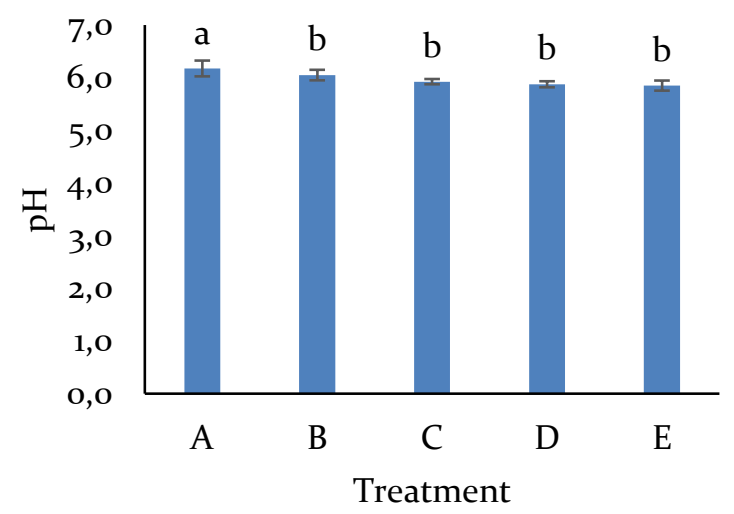

Figure 2. $\mathrm{pH}$ content of goat milk jelly candy incorporated with various concentrations of red dragon fruit peel juice.

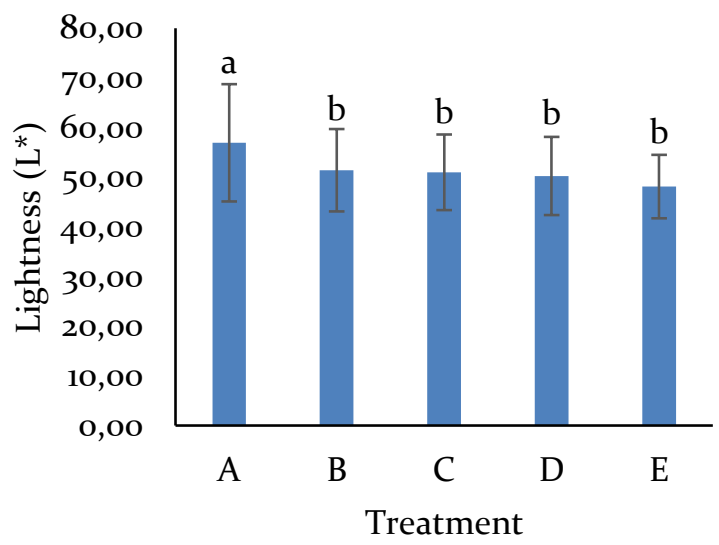
of goat milk jelly candy incorporated with various concentrations of red dragon fruit peel juice

$\mathrm{pH}$ of goat milk jelly candy incorporated with various concentrations of red dragon fruit peel juice is could be seen in Figure 2. Treated samples exhibited lower $\mathrm{pH}$ compared to control $(\mathrm{P}<0.05)$, while $\mathrm{pH}$ among dragon fruit peel-incorporated samples were comparable $(\mathrm{P}>0.05) . \mathrm{pH}$ of dragon fruit peel juice (5.4) was directly attributed to $\mathrm{pH}$ of goat milk jelly candy produced. Oxalic, citric, malic, succinic, and fumaric acids with total of $0.80,0.08$, $0.64,0.19,0.01 \%$ of its total organic acids were responsible for $\mathrm{pH}$ of dragon fruit peel [13].

Lightness $\left(\mathrm{L}^{*}\right)$, redness $\left(\mathrm{a}^{*}\right)$, and yellowness $\left(\mathrm{b}^{*}\right)$ of goat milk jelly candy incorporated with various concentrations of red dragon fruit peel juice are described in Figure 3. Redness of sample was being very important attributes on jelly candy prepared with the addition of red dragon fruit peel. Due to its intense color, redness of sample was increased by higher concentration of red dragon fruit peel, while lightness and yellowness were decreased. A research reported that redness of red dragon fruit peel was 39.3 [14].

Redness on the samples was associated with natural pigment, betacyanin, on red dragon fruit peel. A reference explained that betacyanin in dragon fruit were divided into three types i.e. betanin, phyllocactin dan hylocerenin [15]. Nevertheless, betanin is major betacyanin type on red dragon fruit peel. Thus, this pigment was directly contributed to provide various redness level among samples. 


\section{Conclusion}

Sample treated with $4 \%$ of red dragon fruit juice might economically reasonable. Nevertheless, incorporation of $8 \%$ of red dragon fruit peel juice produces more intense redness color of jelly candy. Thus, the latter concentration was considered as the most attractive color and could be applied as potential natural colorant on jelly candy production.

\section{References}

[1] Nurhayati, G. Kusuma, and Maryanto. 2015. Sifat kimia selai buah naga, komposisi mikroflora dan profil SCFA feses relawan. J. Tekno. Dan Industri Pangan, 26, 213-221.

[2] Panchal, J. B., R. S. Gaikwad, J. K. Dhemre, and U. D. Chavan. 2018. Studies on preparation and storage of jelly from dragon fruit (Hylocereus undatus). Journal of Pharmacognosy and Phytochemistry, 7, 2648-2655.

[3] Zainoldin, K. H., and A. S. Baba. 2009. The effect of Hylocereus polyrhizus and Hylocereus undatus on physicochemical, proteolysis, and antioxidant activity in yogurt. International Journal of Nutrition and Food Engineering, 12, 585-590.

[4] Jayasinghe, O., S. Fernando, and. Hettiarachchi. 2015. Production of a novel fruit-yogurt using dragon fruit (Hylocereus undatus L.). European Scientific Journal, 11, 208-215.

[5] Teguh, R. P. K., I. Nugerahani, and N. Kusumawati. 2015. Pembuatan yogurt buah naga merah (Hylocereus polyrhizus L.): Proporsi sari buah dan susu UHT terhadap viabilitas bakteri dan keasaman yogurt. Jurnal Teknologi Pangan dan Gizi, 14, 89-94.

[6] Hanzen, W. F. E., and U. S. Hastuti, and B. Lukiati. 2016. Kualitas yoghurt dari kulit buah naga berdasarkan variasi spesies dan macam gula ditinjau dari tekstur, aroma, rasa dan kadar asam laktat. Proceeding Biology Education Conference, 13, 849-856.

[7] Ho, L-H. and N. W. B. A. Latif. 2016. Nutritional composition, physical properties, and sensory evaluation of cookies prepared from wheat flour and pitaya (Hylocereus undatus) peel flour blends. Cogent Food \& Agriculture, 2, 1-10.

[8] Analianasari and M. Apriyani. 2017. Characteristics of frozen yoghurt enriched with red dragon fruit skin extracts (Hylocereus polyrhizus). Journal of Physics: Conf. Series 953, 1-8.

[9] Sari, S. M., A. C. Adi., and D. R. Andrias. 2015. Daya terima dan total cost kombinasi sari kulit buah naga merah dan sari buah jambu biji merah. Media Gizi Indonesia, 10, 128-135.

[10] Utama, T. P. 2015. Karakteristik mutu permen jeli dadih susu sapi dengan penambahan ekstrak daun sirsak sebagai pangan fungsional. Bachelor thesis. Faculty of Animal Science. Universitas Andalas.

[11] AOAC. 2005. Official Methods of Analysis of AOAC International. 18th ed. Association of Official Analytical Chemists. Mariland.

[12] Yati, K., V. Ladeska, and A. P. Wirman. 2017. Isolati pectin dari kulit buah naga (Hylocereus polyrhizus) dan pemanfaatannya sebagai pengikat pada sediaan pasta gigi. Media Farmasi, 14, 1-16.

[13] Jamilah, B., C. E. Shu, M. Kharidah, M. A. Dzulkifly, and A. Noranizan. Physico-chemical characteristics of red pitaya (Hylocereus polyrhizus) peel. International Food Research Journal, 18, 279-286.

[14] Chik, C. T., A. Abdullah, and N. Abdullah. 2011. Quality characteristics and acceptability of three types of pitaya fruits in a consumer acceptance study. Journal of Tourism, Hospitality \& Culinary Arts. 3, 89-98.

[15] Naderi, N., H. M. Ghazali, A. S. M. Hussin, M. Amid, and M. Y. A. Manap. 2012. Characterization and quantification of dragon fruit (Hylocereus polyrhizus) betacyanin pigments extracted by two procedures. Pertanika J. Trop. Agric. Sci., 35, 33-40. 